\title{
LANGUAGE LEARNING STRATEGIES EMPLOYED BY SUCCESSFULL STUDENTS IN DEVELOPING ENGLISH-SPEAKING PERFORMANCE
}

\author{
${ }^{1}$ Heriyanti Tahang, ${ }^{2}$ Sarmin, ${ }^{3}$ Yuliana A, ${ }^{4}$ Taslim \\ ${ }^{1}$ Department of English Education, Faculty of Teacher Training and Education, Universitas \\ Muhammadiyah Sorong \\ ${ }^{2}$ Department of English Education, Faculty of Teacher Training and Education, Universitas \\ Muhammadiyah Sorong \\ ${ }^{3}$ Department of English Education, Faculty of Teacher Training and Education, Universitas \\ Muhammadiyah Sorong \\ ${ }^{4}$ STKIPM Bone
}

Email:1heriyanti7@gmail.com, sarminbau2@gmail.com, ulhyjuliana@gmail.com, taslimtawe@gmail.com

\begin{abstract}
This research aimed to discover the language learning strategies used by successfull students in developing speaking performance in speaking performance at English Language Education Program in Universitas Muhammadiyah Sorong. This research used qualitative method in the form of descriptive qualitative. the participants of this research were taken from the third semester of English Language Education Program in Universitas Muhammadiyah Sorong with the total 6 students. The participants were the students who gained score A in speaking class. Based on the data gathered, the result showed that the students applied both of Direct and Imdirect learning strategies in developing their speaking English Language Education Program in Universitas Muhammadiyah Sorong, namely social strategies, metacognitive strategies, affective strategies in Indirect Strategy and memory strategies, cognitive strategies, and compensation strategies in Direct Strategy. From those of six strategies applied, most of the students tended to apply Indirect Strategy that was social strategies by asking help, working in pair, practicing with the proficient user of English and making small group discussion.
\end{abstract}

\section{Key Words: Language Learning Strategies, Speaking Performance}

\section{INTRODUCTION}

Learning strategies become one of the factors how the students can control their learning process. According to Oxford (1990: 8) language learning strategies help learners participate actively in such authentic communication and encourage the development of communicative competence. It shows that the effect of learning strategies is very significance to develop English skill especialy in communication. Furthermore, enriching students' awareness on their own learning strategies, it would help them to evaluate their own strategies effectiveness and their own learning (Yunus: 
2913). It can be concluded that the learners of English really need to know language learning strategies to make students easier in learning English.

The problem of this research was formulated as follows: "What are language learning strategies used by successfull students in developing speaking performance based on Oxford Theory at English Language Education Program in Universitas Muhammadiyah Sorong.

\section{RESEARCH METHODOLOGY}

Research Method and Design

In this research the researcher used qualitative research on descriptive qualitative to investigate the language learning strategy used by students in developing their speaking performance.

Setting of the Research

This research was conducted in Universitas Muhammadiyah Sorong located at Jalan Pendidikan Number 27. It was one of the Universities in Sorong City, West Papua. The process of data collection in six time until the data saturated. It was conducted at the beginning of new semester. It was started from the end of September until the beginning of November.

\section{Participant of the Research}

The participants of the research were taken from the students of English Language Education Program. It was at the third semester in academic year 2017/2018. The research took 6 participants. This research applied purposive sampling where participants should have the characteristics as follows:

1. The participants of the research were from the third semester students of English Language Education Program in Universitas Muhammadiyah Sorong in akadec year 2017/2018.

2. The participants were successful in class Speaking One and Speaking Two.

3. The students had an excellent speaking performance. The students' speaking performance were taken based on their speaking scores. Speaking score A was taken as represented speaking performance in their Speaking Class in English Language Education Program in Universitas Muhammadiyah Sorong. 


\section{Instrument of the Research}

Instrument of the research, the researcher used interview based on Oxford theory about Language Learning Strategy. The researcher applied semi-structure interview where in the process of collecting the data, the researcher listed the guidance questions and the further questions developed in the process of interview. Dawson (2002: 28-29) said that Semi-structured interview became the most common type of interview used in qualitative social research where the researcher could just list the specific questions to be discussed. The instruments used were recording and interview guideline. There were 12 interview questions guideline which was divided into 2 questions for each language learning strategies they are Direct and Indirect Strategy. Interview guideline was used as the guidance of the researcher to make the process of interview running well while recording was used to record the students speech during interview process.

Technique of Data Collection

In collecting data, the researcher applied Interview. Interview was conducted after having speaking class but in the process of speaking class. Interview was done after class to make the participants having a free space in responding the questions given by researcher. The researcher conducted interview for six times. Interview was conducted in every meeting of speaking class. It was conducted to find out the students' language learning strategy in learning speaking. After that, the researcher transcribed the data in recording and translated it into English. Then, The researcher analyzed and gave the conclusion of the research.

\section{FINDING AND DISCUSSION}

\section{Findings}

In finding, researcher would show the students' language learning strategies used in speaking performance. It was taken based on interview process towards the students for six meetings. 
The number of students' language learning strategies gained categorized further as follows:

Table 4.2. List of Students' Language Learning Strategies Used

\begin{tabular}{cccccccc}
\hline & \multicolumn{7}{c}{ Language Learning Strategies Components Used } \\
Student & \multicolumn{2}{c}{ Direct Strategies } & \multicolumn{2}{c}{ Indirect Strategies } & \\
& Memory & Cognitive & Compensation & Metacognitive & Affective & Social & \\
& Strategies & Strategies & Strategies & Strategies & Strategies & Strategies \\
\hline I & 2 & 2 & 1 & 2 & 2 & 3 & 12 \\
II & 2 & 2 & 2 & 4 & 3 & 3 & 16 \\
III & 3 & 1 & 2 & 4 & 2 & 4 & 16 \\
IV & 2 & 2 & 1 & 4 & 2 & 3 & 14 \\
V & 2 & 2 & 1 & 1 & 4 & 5 & 15 \\
VI & 2 & 1 & 1 & 3 & 2 & 2 & 11 \\
\hline Total & $\mathbf{1 3}$ & $\mathbf{1 0}$ & $\mathbf{8}$ & $\mathbf{1 8}$ & $\mathbf{1 5}$ & $\mathbf{2 0}$ & $\mathbf{8 4}$ \\
\hline
\end{tabular}

Based on the table above, from 6 students, It could be seen that students expressed Indirect Strategy mostly. They are social strategies, then metacognitive strategies and the affective strategies. The Indirect Strategy used by students in three order frequency also, they are memory strategies, the cognitive strategy and the lowest frequency is compensation strategies.

Discussion

Based on the findings mentioned before, researcher would discuss it related to the students' language learning strategies. The discussion of this research reflected the theories of Oxford (1990) that had been explained in chapter II. Each of the strategies used by the students would be discussed from the higest untill the lowest frequency, as follows:

a. Social Strategies

Most of the students of semester 3 who were successful in speaking class tended to apply social strategies. The students applied social strategies by asking a help, working in pair, practicing with the proficienct user of English, and making small group discussion. Asking a help or question was done when the students get the difficulties in translating new words in English. It was also conducted to ask 
correction or clarification related to the material that had not been understood. Then, the students worked in pairs to improve their English Language Education Program in Universitas Muhammadiyah Sorong in practicing English intensively. It was almost same with the implementation of small group discussion to make the students accustomed in explained the current issues in English. Students also looked for the proficient user of English like native speaker to make the students having a space to measure their English Language Education Program in Universitas Muhammadiyah Sorong in using English correctly.

Oxford (1990) stated that there were three kinds of social strategies, they were asking question cooperating with others and emphatizing with others. The students of semester three tended to conduct asking question and cooperating such as working in pairs. There was new strategy gained by the researcher that correlated with social strategies, that was learning by implementing group discussion.

b. Metacognitive strategies

The second strategy used by students was Metacognitive Strategies. The students tended to do Preparation before class and in the end of their learning they would evaluate it. Preparation would be conducted to gain the comprehension of the material that would be brought by the lecturer. The students would prepare such material, vocabularies, concept of speech, and the knowledge related to the topic. The material was gained by their own selves, reading book, and accessing internet. Then, Evaluation would be the way to review the lack during learning process. It could be like paying attention to the verbal assesment given by lecture, asking an explanation from other people, and getting back to see their notes. According to Oxford (1990) said that there are three sets of metacognitive strategies, two of them were planning and evaluating the learning. Those sets in line with the strategies applied by the students in this research.

\section{c. Affective Strategies}

The Students employed Affective strategies by lowering anxiety, encouraging themselves, and handling feeling. students lowered the anxiety by using gestures, praying, trusting to their own English Language Education Program in Universitas Muhammadiyah Sorong, and trying to be relax while speaking. That strategies used 
to apply by students while speaking in front of the classroom. After that, to encourage the students learning, they had embeded motivations in their minds before starting to learn English such they had had a dream to study abroad, boast their parents, and become an English teacher. Then, students handled their feelings and motivations by practicing and sharing with friends, believing to their English Language Education Program in Universitas Muhammadiyah Sorong, and focusing on their dream.

In applying affective strategies, students should comprehend three sets: lowering anxiety, encouraging ourselves, and taking the emotional temperature, Oxford (1990). Those of strategies are also employed in this research to handle the emotion and make the students motivated in learning English.

d. Memory Strategies

This strategy was the fouth strategy used by the students. The students applied that strategy by reading text, listening and watching western movie, and writing new vocabulary in a book. Reading was done to get new vocabulary. Then, they wrote it down or make it in sentence when they were watching western movie or listening western music, they would directly found out the meaning of that new vocabulary in dictionary and write it down. Afterwards, they would read the words that had been written down frequently. Oxford (1990) had explained that memory strategies was used for entering new information in memory storage. It was in line with the strategies employed by the students in which they tend to read text, write new vocabulary, and et cetera to storage new vocabulary in mind. Unfortunately, this strategy can bring a negative manner for students' speaking skill as found by Mistar\& Umamah (2014).

e. Cognitive Strategies

The fifth was cognitive strategies. The students tended to employ this strategy by practicing in natural, memorizing context of speech, and repeating. In cognitive strategies, students mostly chose to practice in natural by speaking in front of the mirror, freetalking, and speaking without using grammar. The students who practiced in front of the mirror would firstly write the point, and find the vocabulary related to the topic before speaking. Memorizing and repeating were done to 
remember the arguments or points that would be spoken up. Repeating sometimes was done while watching Tv to make them familiar with the utterances in English. Oxford (1990) stated that in learning new language, practicing naturalistically became the most significance one in learning new language. In this researcher, students mostly mostly did practice by speaking in front of the mirror naturally.

\section{f. Compensation Strategies}

The last strategy employed by students was compensation Strategies. The students applied it by using gesture, finding the similar meaning, and combining. students used gesture to show off the words that were forgotten while speaking. Finding the similar meaning became the option when the students got stuck in their speaking. Then, combining was used as the last option when they are blank and lost of their mind. Compensation strategies was used to survive while speaking in front of the public or many people. as stated by Oxford (1990) switching to mother tongue and using physical motion became parts of way in overcoming limitation in speaking. The students rarely used this strategy because most of them had done practice English frequently before speaking class. They have got used to speak with friends and many people. Therefore, the tendency of getting stuck while speaking was rare happening.

Based on the discussion above, all language learning strategies applied by the students will be classified in table as follows:

Table 4.3. The Classification of Students' Language Learning Strategies

\begin{tabular}{cll}
\hline $\begin{array}{c}\text { Learning } \\
\text { strategies }\end{array}$ & & \multicolumn{1}{c}{ Components } \\
\hline & $\circ$ & Asking a help \\
Social Strategies & $\circ$ & Working in pair \\
& $\circ$ & Practicing with the proficient user of english \\
& $\circ$ & Making small group discussion \\
\hline Metacognitive & $\circ$ & Preparation material \\
Strategies & $\circ$ & Evaluation the learning \\
\hline Affective & $\circ$ & Lowering anxiety \\
\hline
\end{tabular}




\begin{tabular}{cll}
\hline Strategies & $\circ$ & Encouraging our own selves \\
& $\circ$ & Handling feeling \\
\hline Memory & $\circ$ & Reading text \\
Strategies & $\circ$ & Listening and watching western movie \\
& $\circ$ & Writing new vocabulary \\
\hline Cognitive & $\circ$ & Practicing in natural \\
Strategies & $\circ$ & Memorizing the context of speech \\
& $\circ$ & Repeating \\
\hline Compensation & $\circ$ & Using gestures \\
Strategies & $\circ$ & Finding the similar meaning \\
& $\circ$ & Combining \\
\hline
\end{tabular}

\section{CONCLUSION AND SUGGESTION}

Conclusion

Based on the findings and discussion at the previous chapter, the researcher concluded that the successfull students in developing speaking performance of third semester of English Language Education Programat Universitas Muhammadiyah Sorong applied six kinds of learning strategies in speaking performance namely social strategies, metacognitive strategies, affective strategies, memory strategies, cognitive strategies, and compensation strategies. It also concluded by Gani, et.all (2015) on their research that High Speaking Performance Students usually used all six strategies to enhance their speaking skill more equally. It also found by Halbach (2000) and Mistar et all (2018) that the successful students use the learning strategy to a greater extent than the less successful students. Based in this conclusion, encouraging student's awareness on learning strategies would give more help to students in enhancing their understanding in teaching and learning process.

Most of the students tended to use social strategies of all strategies. It was applied by asking a help, working in pair, practicing with the proficienct user of English, and making small group discussion. The result is also supported by Suwanarak (2015) who revealed on his research that the learners had reported an overall preference for using the social strategies in learning. Then, metacognitive strategies was applied 
by doing preparation and evaluation after speaking class. affective strategies was employed by lowering anxiety, encouraging themselves, and handling feeling. It was followed by memory strategies applied by reading text, listening and watching western movie, and writing new vocabulary in a book. Cognitive strategies was done by practicing in natural, memorizing context of speech, and repeating. The last strategies, compensation strategies was employed by using gesture, finding the similar meaning, and combining.

Suggestion

The researcher would like to present some suggestions to students and teacher/ lecturers to improve the interest in learning speaking as follow:

1. The students should comprehend the concept of language learning strategies before learning new language.

2. The students can apply social strategies in improving their speaking performance.

3. The lecturers are recommended to apply social strategies towards the students in the process of teaching speaking.

4. Lecturer or teacher need to be more attention on students' need by paying attention on their learning strategies used in order to accommodate the student's developmental needs and differences (Chen: 2014).

\section{BIBLIOGRAPHY}

Brown, H.G. 2004. Language Assessment:Principles And Classroom Practices. Newyork: Longman

Cameron, L. (2001). Teaching languages to young learners. Ernst Klett Sprachen.

Chen, M.L. 2014. Age Differences in the Use of Language Learning Strategies. Canadian Center of Science and Education. International journal of English Language Teaching, Vol. 7, No. 2.

Dawson, D. C. 2002. Practical Research Methods. United kingdom. Oxford

Richards, J. C., \& Renandya, W. A. (Eds.). (2002). Methodology in language teaching: An anthology of current practice. Cambridge university press.

Suwanarak, K. 2015. Learning English as Thai Adult Learners: An Insight into Experience in Using Learning Strategies. Canadian Center of Science and Education. International journal of English Language Teaching, Vol. 8, No. 12. 
Jonassen, D.H. 1985. Learning strategies: A new educational technology. Programmed Learning and Educational Technology.

Jones, b.f., sullivan palincsar, a., sederburg olge, d., \& glynn carr, e. (eds.). 1987. Strategic Teaching and Learning: Cognitive Instruction in the Content Areas. Alexandria, Va: Association for Supervision and Curriculum Development.

Miles, M. B., Huberman, A. M., Huberman, M. A., \& Huberman, M. (1994). Qualitative data analysis: An expanded sourcebook. sage.

Mistar, J \& Umamah, A. 2014. Strategies of Learning Speaking Skill by Indonesian Learners of English and Their Contribution to Speaking Proficiency. TEFLIN Journal, Vol. 25, No. 2, July.

Gani, A, SFajrina, D., \& 2015. Students' Learning Strategies for Developing Speaking Ability. STUDIES IN ENGLISH LANGUAGE AND EDUCATION, 2 (2), 16-28.

Mistar, J., Zuhairi, A., \& Umamah, A. 2018. Strategies of Learning Speaking Skill by Senior High School EFL learner inIndonesia. The ASIAN EFL Journal, Vol. 20, Issued 5, May.

Halbach, A. 2000. Finding out about Students' Learning Strategies by looking at their diaries: A Case Study. SYSTEM 28, 85-96.

Oxford, R. L. 1990. Language Learning Strategies: What Every Teacher Should Know. New York: Newbury House Publishers.

Rubin, J., \& Thompson, I. 1994. How to be a More Successful Language Learner. 2nd Ed. Boston: Heinle \& Heinle.

Weinstein, C.E., \& Mayer, R.E. 1986. The teaching of learning strategies. New York, NY: Macmillan.

Yunus, M.M., Sulaiman, N.A., \& Embi, M.A. 2013. Malaysian Gifted Students' Use of English Language Learning Strategies. Canadian Center of Science and Education. International journal of English Language Teaching, Vol. 6, No. 4. 